\title{
Greenhouse evaluation of Beauveria bassiana (Balsamo) Vuillemin against Aphis craccivora (Das) on Fenugreek
}

\author{
K. Selvaraj* and H. D. Kaushik \\ Department of Entomology, CCS Haryana Agricultural University, Hisar-125004, INDIA \\ *Division of Crop Protection, Central Research Institute for Jute and Allied Fibres, Kolkata-700120, INDIA \\ *Corresponding author. E-mail: selvaentomo@yahoo.co.in
}

Received: September 02, 2014; Revised received: November 28, 2014; Accepted: December 20, 2014

\begin{abstract}
The bioassay studies were carried out to determine the $\mathrm{LC}_{50}$ and $\mathrm{LT}_{50}$ of Beauveria bassiana against Aphis craccivora on fenugreek under greenhouse conditions. The results revealed that, the cumulative corrected mortality $(\mathrm{CCM})$ was $43.50 \%$ at higher concentration $\left(1 \times 10^{10}\right.$ spores $\left./ \mathrm{ml}\right)$ and it was $20.85 \%$ at lowest concentration $\left(1 \times 10^{4}\right.$ spores $\left./ \mathrm{ml}\right)$ at one day after treatment (DAT). The CCM decreased with decreasing conidial spore concentration. Likewise, at 2, 3, 4, 5, 6 and 7 DAT, almost same trend was observed. At 7 DAT, the CCM was $85.04 \%$ and $55.21 \%$ at $1 \times 10^{10}$ spores $/ \mathrm{ml}$ and $1 \times 10^{4}$ spores $/ \mathrm{ml}$, respectively. The $L_{50}$ value of $B$. bassiana against $A$. craccivora was $1.2 \times 10^{8}$ spores $/ \mathrm{ml}$. Mean lethal time $\left(\mathrm{LT}_{50}\right)$ values were worked out 73, 89, 97, 112, 126, 138 and 157 hours for $10^{10}, 10^{9}, 10^{8}, 10^{7}, 10^{6}, 10^{5}$ and $10^{4}$ spores $/ \mathrm{ml}$, respectively. By testing the field efficacy of $B$. bassiana against $A$. craccivora, this insect pathogenic fungus can be used as potential biocontrol agent for the sustainable management of aphid in fenugreek crop.
\end{abstract}

Keywords: Aphis craccivora, Beauveria bassiana, $\mathrm{LC}_{50}, \mathrm{LT}_{50}$ value, Pathogenicity

\section{INTRODUCTION}

Fenugreek (Trigonella foenum-graecum L.) is an important seed spice crop in India and mainly used as spice for flavouring almost all vegetable dishes and pickles. The fresh tender leaves and stems of this crop are consumed as curried vegetable (Yadev et al., 2013). The green as well as mature stalks of fenugreek constitute a good fodder for farm animals, and also widely used as a green manure (Singh et al., 2008). Besides, seeds reported to possess several medicinal properties (Meghwal and Goswani, 2012). The fenugreek leaf extracts have been reported to show a repellent activity against various stored grain insect pests (Farhana et al., 2006), antifeedant property against some insect pests (Thomas et al., 2002) and also have fungitoxic principle (AI-Rahmah et al., 2013). Fenugreek crop is mainly attacked by aphid, alfalfa weevil, leaf miner. Among these insect pests, Aphis craccivora (Koch) was the most important in India and quite often proved as the yield limiting factors for the successful seed production. A. craccivora is not only as it causes quantitative and qualitative losses in the grain yield but also deteriorate the quality of green leaves by sucking cell sap and secreting honeydew. The honeydew secretion of the aphids provide suitable media for the development of the sooty moulds and fungi which ultimately hamper the process of photosynthesis. Yield losses caused by A. craccivora on fenugreek were even up to $68.80 \%$
(Sharma and Kalra, 2002; Deshwal, 2007).

At present, fenugreek aphid is mostly controlled by chemical insecticidal applications. Fenugreek leaves are often consumed as leafy vegetables. So the growing demand for reducing chemical inputs in fenugreek crop ecosystem and increased resistance to insecticides have provided great impetus to the development of alternative forms of aphid control in fenugreek crop. Moreover, it is a difficult pest to control with insecticides because of its polyphagous nature with very short life cycle and high reproduction rates. Major emphasis is given on biocontrol approaches in the present context of environmental safety. Biological control of insect pests using entomopathogenic fungi (EPF) are gaining importance due to their target specificity, self-perpetuity and obvious environmental safety. The use of fungal biological control agents is a rapidly developing field and is increasingly being adopted and accepted worldwide for management of agricultural pests (Hajek and Delalibera, 2010).

Fungi have been considered the principal group of aphid pathogens, the most prevalent and widely encountered species belonging to the order Zygomycetes. In particular environments (Greenhouse/tropical regions) Deutermycetous species also significantly reduce aphid numbers (Suresh et al., 2012). Fungi are the only insect pathogens currently used for the control of aphids (Latge and Papierok, 1988) and species like, 
Beauveria bassiana, Fusarium pallidoroseum, Lacanicilium lecanii and Isaria fumosoroseus were responsible for epizootics that often successfully regulate aphid population (Milner, 1997; Chen and Feng, 1999; Kim et al., 2008). Therefore, B. bassiana could be more appropriate for management of insect pests with piercing sucking mouth parts which are unlikely to ingest microbes upon their feeding (Wraight and Carruthers, 2010). However, full potential of EPF is yet to be exploited for management of many aphid species infesting several cultivated crop plants. Keeping these in view, the present study was undertaken to study pathogenicity of $B$. bassiana against $A$. craccivora on fenugreek under greenhouse conditions.

\section{MATERIALS AND METHODS}

The experiments were conducted during October, 2007 to March, 2008 in the greenhouse of Department of Entomology, CCS Haryana Agricultural University, Hisar, Haryana, India.

Culture of Beauveria bassiana: The culture of aphid specific B. bassiana $\mathrm{HaBa}$ (Hyderabad) strain was raised on potato dextrose agar slants in $250 \mathrm{ml}$ conical flasks following the standard method (Vimaladevi, 2005). Regular passage was done for further multiplication and maintenance which was done at $25 \pm 2{ }^{\circ} \mathrm{C},>90 \%$ relative humidity and 16 :8h light: dark. The fungal isolate was sub-cultured once in a month and after every 5-6 sub-culturing again re-isolated for further studies to maintain the virulence of the strain.

Preparation of $\boldsymbol{B}$. bassiana spore suspension: Aqueous conidial suspension was made from conidia harvested from the slants preferred in conical flasks after 14 days of inoculation. Tween $80(0.02 \%)$ was used to disperse the conidia uniformly in the solution. The conidial suspension was filtered through double layer muslin cloth to remove the mycelial mat. A suspension of $1 \times 10^{10}$ conidia $\mathrm{ml}^{-1}$ concentration was made using haemocytometer counts. The lower conidial concentrations were obtained from the serial dilutions technique for bioassay studies.

Bioassay studies: For bioassay studies 32 fenugreek plants were grown in pots (one plant/pot). All agronomic practices were practiced in greenhouse under semi natural conditions. The aphid culture was maintained until all experiments were completed. Seven treatments comprising various spore suspensions $\left(10^{10}, 10^{9}, 10^{8}\right.$, $10^{7}, 10^{6}, 10^{5}$ and $10^{4}$ spores $/ \mathrm{ml}$ ) were sprayed on the infested twigs of fenugreek plant having counted number of aphids and each treatment were replicated four times. One control treatment (water + Tween 80 $(0.02 \%)$ spray only) was maintained alongside. The greenhouse temperature and relative humidity was $27 \pm 2^{\circ} \mathrm{C},>90 \%$ respectively and $16: 8 \mathrm{~h}$ light: dark.

Determination of $\mathbf{L C}_{\mathbf{5 0}}$ and $\mathbf{L T}_{\mathbf{5 0}}$ : Daily observations on aphid mortality were continued for 7 days. The cadavers showing mycosis were considered to be dead as a result of infection by the fungus. To determine $\mathrm{LT}_{50}$ values, the observations on aphid mortality were recorded at 24 hours interval for 7 days. Mortality data was corrected with that in control by using the Abbott's formula (Abbott, 1925).

Statistical analysis: The data was then analyzed by probit analysis (Finney, 1971). One-way analysis of variance (ANOVA) was conducted on the mortality data to test the level of significance of the difference in response between the treatments. To assess virulence of the strain, full logarithmic plots of insect mortality against concentration was analyzed assuming the probit mode (Finney, 1971). Log concentration, probability regression (including a control mortality correction as an offset for natural mortality) was estimated using probit analysis in each case. These equations allowed us to determine the $\mathrm{LC}_{50}$ i.e. lethal concentration required for $50 \%$ mortality of the test stage of the insect and $\mathrm{LT}_{50}$ lethal time required for 50 $\%$ mortality of the test stage of the insect.

\section{RESULTS AND DISCUSSION}

Entomopathogenic fungi that parasitize insects are valuable weapons for biocontrol and play an important role in promoting integrated pest management. To date, various strains of EPF such as Lecanicillium sp., B. bassiana, Metarhizium anisopliae, Paecilomyces sp. and Nomuraea rileyi have been used to control aphids (Vu et al., 2007; Kim et al., 2008; Selvaraj et al., 2010). It is well known for EPF isolates of the same species to exhibit different biological and ecological differences when challenged against the same insect species. Therefore, one of the first important steps in the development of an effective microbial control agent is careful evaluation and selection of the appropriate isolate based on virulence against the target pest. Moreover, large discrepancies between field and laboratory results have made it difficult to predict the real effects these fungi have on both target and non-target insects due to several factors are differences in exposures and differences in environmental conditions. Present investigation targeted to study the effect of greenhouse conditions on pathogenicity of A. craccivora. There are several biopesticides based on EPF available in the market for use against insect pests in greenhouse ecosystems. Mycoinsecticide is the use of fungi in biological processes to lower the insect density with the aim of reducing disease producing activity and consequently crop damage.

Pathogenicity of $B$. bassiana against $A$. craccivora: During the period of study, the population buildup of aphids was noticed vegetative stage to flowering stage that it ranged between 50 to 110 numbers per plant. In present studies, the results revealed that one day after treatment the cumulative corrected mortality was $43.50 \%$ at higher concentration $\left(1 \times 10^{10}\right.$ spores $\left./ \mathrm{ml}\right)$ and it was $20.85 \%$ at low concentration $\left(1 \times 10^{4} \mathrm{spores} / \mathrm{ml}\right)$ 
Table 1. Cumulative corrected mortality (\%) of A. craccivora by B. bassiana under greenhouse conditions.

\begin{tabular}{lccccccc}
\hline \multirow{2}{*}{$\begin{array}{c}\text { Concentration } \\
\text { spores/ml) }\end{array}$} & \multicolumn{7}{c}{ Cumulative corrected mortality $(\%)$} \\
\cline { 2 - 8 } & 1DAT* & 2 DAT & 3 DAT & 4 DAT & 5 DAT & 6 DAT & 7 DAT \\
\hline $1 \times 10^{10}$ & 43.50 & 52.52 & 57.36 & 63.76 & 68.53 & 73.64 & 85.04 \\
& $(41.24) * *$ & $(44.12)$ & $(49.29)$ & $(52.81)$ & $(55.22)$ & $(58.67)$ & $(67.59)$ \\
$1 \times 10^{9}$ & 40.88 & 50.76 & 53.07 & 59.48 & 62.23 & 72.84 & 79.19 \\
& $(39.50)$ & $(42.40)$ & $(46.98)$ & $(50.45)$ & $(52.21)$ & $(58.34)$ & $(66.79)$ \\
$1 \times 10^{8}$ & 35.28 & 44.04 & 49.14 & 55.89 & 58.09 & 71.88 & 75.39 \\
& $(36.55)$ & $(39.50)$ & $(44.69)$ & $(48.13)$ & $(49.87)$ & $(56.45)$ & $(64.50)$ \\
$1 \times 10^{7}$ & 30.54 & 41.02 & 46.41 & 50.72 & 56.91 & 63.47 & 70.84 \\
& $(33.50)$ & $(37.15)$ & $(42.97)$ & $(45.26)$ & $(48.71)$ & $(52.81)$ & $(58.99)$ \\
$1 \times 10^{6}$ & 28.81 & 32.75 & 41.78 & 47.75 & 54.71 & 59.07 & 64.99 \\
& $(32.25)$ & $(35.35)$ & $(40.09)$ & $(43.54)$ & $(47.56)$ & $(50.48)$ & $(57.71)$ \\
$1 \times 10^{5}$ & 26.81 & 32.26 & 34.51 & 43.95 & 49.34 & 52.73 & 60.88 \\
& $(30.96)$ & $(34.74)$ & $(35.95)$ & $(41.24)$ & $(44.69)$ & $(46.41)$ & $(54.00)$ \\
$1 \times 10^{4}$ & 20.85 & 21.51 & 32.26 & 41.23 & 40.22 & 50.21 & 55.21 \\
& $(26.90)$ & $(27.61)$ & $(34.74)$ & $(40.09)$ & $(39.36)$ & $(45.26)$ & $(51.04)$ \\
$\mathrm{S} . \mathrm{Em} . \pm$ & 0.18 & 0.71 & 0.46 & 0.16 & 0.16 & 0.18 & 0.20 \\
$\mathrm{CD}(\mathrm{P}=0.05)$ & 0.53 & 0.51 & 0.56 & 0.49 & 0.49 & 0.55 & 0.59 \\
\hline
\end{tabular}

*DAT-Days after treatment; ** Values given in parenthesis are arc sin transformed.

Table 2. Probit analysis of concentration-mortality response of coriander aphid, A. craccivora to B. bassiana under greenhouse conditions.

\begin{tabular}{lccc}
\hline Aphid & Chi-square & Regression equation & LC $_{\mathbf{5 0}}(\mathbf{s p o r e s} / \mathbf{m l})$ \\
\hline A. craccivora & $2.638 \mathrm{NS}^{*}$ & $\mathrm{Y}=3.5885+0.245 \mathrm{X}$ & $1.2 \times 10^{8}$ \\
\hline
\end{tabular}

(Table 1). It is evident from the data that the insect species was susceptible to fungal infection. The CCM was decreased with decreasing fungal conidial concentration. Similarly, at 2, 3,4,5,6 and 7 DAT almost same trend was observed. Moreover, the CCM was increased with increased exposure time. At 7 DAT, the highest CCM $(85.04 \%)$ was observed at the highest concentration $\left(1 \times 10^{10}\right.$ spores $\left./ \mathrm{ml}\right)$ and at lowest concentration $\left(1 \times 10^{4}\right.$ spores $\left./ \mathrm{ml}\right)$, it was $55.21 \%$. The results described herin are in accordance with Nirmala et al. (2006) who reported the twelve fungal isolates belonging to $B$. bassiana, $M$. anisopliae, and Verticillium lecanii were pathogenic to A. craccivora, Aphis gossypii and Rhapalosiphum maidis. Similar results were obtained when individual of Schizaphis graminum and Rhopalosiphum padi were exposed to the $B$. bassiana and the highest concentration i.e. $1 \times 10^{8}$ spores/ml showed the maximum percent mortality on the seventh day of fungus treatment (Akmal et al., 2013). Treatment of green peach aphid adults with isolates of B. bassiana in the greenhouse resulted in 30.7 to $48.3 \%$ infection rates. The highest infection rate was achieved using the isolate GHA followed by BAU018, BAU019 and BAU004 with no significant differences among them (Al-alawi and Obeidat, 2014).

Determination of $\mathbf{L C}_{\mathbf{5 0}}$ and $\mathbf{L T}_{\mathbf{5 0}}$ value for A. craccivora: In the present studies, the $\mathrm{LC}_{50}$ value of $B$. bassiana was $1.2 \times 10^{8}$ spores $/ \mathrm{ml}$ against $A$. craciivora using the data on 3 DAT (Table 2 ). Feng et al. (1990) reported that the $\mathrm{LC}_{50}$ values for their $B$. bassiana strain were $8.2 \times 10^{4}$ conidia/ml on Diuraphis noxia; $2.1 \times 10^{5}$ on Schizaphis graminum; $3.3 \times 10^{5}$ on Metapolophium dirhodum; $1.1 \times 10^{5}$ on Sitobion avenae; $2.1 \times 10^{6}$ on Rhopalosiphum maidis and $3.3 \times 10^{6}$ on $R$. padi under greenhouse conditions. Aswini (2006) found that Fusarium semitectum were effective against the early and late instars of sugarcane woolly aphid at $2.7 \times 10^{9}$ spores/ml (62\% mortality) under both laboratory and greenhouse trials. Saranya et al. (2010) recorded the lowest $\mathrm{LC}_{50}$ value of $2.5 \times 10^{4}$ spores /ml for $V$. lecanii and Hirsutella thompsonii isolates, which showed higher virulence as compared to other isolates against $A$. craccivora. The $\mathrm{LC}_{50}$ values of $B$. bassiana, $M$. anisopliae and Cladosporium oxysporum were $4.5 \times 10^{4}, 8.9 \times 10^{5}$ and $7.4 \times 10^{5}$ spores/ $\mathrm{ml}$ respectively. $\mathrm{LT}_{50}$ value of $B$. bassiana was 73,89 , $96,112,126,138$ and 157 hours for $10^{10}, 10^{9}, 10^{8}, 10^{7}$, $10^{6}, 10^{5}, 10^{4}$ spores $/ \mathrm{ml}$, respectively (Table 3 ). $\mathrm{LT}_{50}$ values decreased with increasing concentration of $B$. bassiana and at highest concentration of $1 \times 10^{10}$ spores $/ \mathrm{ml}, 50 \%$ mortality was achieved in 73.24 hours after treatment and it was 157.39 hours at lowest concentration of $1 \times 10^{4}$ spores $/ \mathrm{ml}$. The mortality in infected aphids with $B$. bassiana increased with increase in spore concentration of conidial suspensions and exposure time. The $\mathrm{LT}_{50}$ values were found to be inversely proportional to the spore concentrations. These findings were in close agreement with Liu et al. 
Table 3. Probit analysis of time-mortality response of A. craccivora to B. bassiana under greenhouse conditions.

\begin{tabular}{lccc}
\hline $\begin{array}{l}\text { Concentration } \\
\text { (Spores/ml) }\end{array}$ & Chi-square & Time mortality response & \\
\cline { 2 - 4 } & 19.37 & $\mathrm{Y}=0.682+4.9634 \mathrm{X}$ & LT $_{\mathbf{5 0}} \mathbf{( h r s . )}$ \\
\hline $1 \times 10^{10}$ & 33.11 & $\mathrm{Y}=1.415+3.94 \mathrm{X}$ & 73 \\
$1 \times 10^{9}$ & 21.67 & $\mathrm{Y}=2.2334+2.84 \mathrm{X}$ & 89 \\
$1 \times 10^{8}$ & 28.96 & $\mathrm{Y}=3.2791+1.21 \mathrm{X}$ & 97 \\
$1 \times 10^{7}$ & 25.87 & $\mathrm{Y}=0.6104+3.97 \mathrm{X}$ & 112 \\
$1 \times 10^{6}$ & 30.82 & $\mathrm{Y}=3.603+1.25 \mathrm{X}$ & 126 \\
$1 \times 10^{5}$ & $2.04 \mathrm{NS}^{*}$ & $\mathrm{Y}=0.011+4.167 \mathrm{X}$ & 138 \\
$1 \times 10^{4}$ & & & 157 \\
\hline
\end{tabular}

NS=Non-significant

(2002) and Wright et al. (2005) who found the susceptibility of target insect to fungal infection is dose -time dependent. Median $\mathrm{LT}_{50}$ values for B. bassiana, $H$. thompsonii, $V$. lecanii, $C$. oxysporum and $M$. anisopliae were 3.63, 3.64, 3.90, 5.24 and 5.54 days, respectively (Saranya et al., 2010). The $\mathrm{LT}_{50}$ values at all concentrations varied between the pathogen and aphid host with $B$. bassiana tending to kill aphid more rapidly. Ibrahim et al. (2011) estimated $\mathrm{LT}_{50}$ values of $B$. bassiana strains LIM1 and $\mathrm{LIB}_{1}$ for $M$. persicae adults at $10^{5}$ conidia $\mathrm{ml}^{-1}$ were 6.8 and 5.6 days, respectively. Increase of conidial concentration by a 1000 fold significantly reduced aphid population by $50 \%$ in less than one day. Opined that significant variations between the times required for each isolate to acquire $50 \%$ death were observed 7 days after inoculation. However, all isolates appeared to be fast killing fungi requiring one or two days for reducing aphid population by half.

These findings suggest that B. bassiana is ideal for further development as a microbial pesticide to control of aphids. B. bassiana might be an excellent candidate for the development as a microbial control agent against $A$. craccivora in fenugreek crop. Aphids possess piercing sucking mouth parts by which they suck plant sap from the conductive tissues. This feeding behavior might result in avoidance of the ingestion of many microbial control agents such as bacteria and viruses which need to be ingested to infect their hosts. On the contrary, EPF cause infection by direct penetration through their host cuticle which makes them excellent candidates as microbial control agents against pests with piercing sucking feeding behavior (Wraight and Carruthers, 2010).

\section{Conclusion}

It is evident from the results that the A. craccivora was susceptible to infection of $B$. bassiana isolates under greenhouse conditions. The mortality observed was low on day 1-2 after treatment in all fungal concentrations, it increased gradually and maximum mortality was obtained on day 4-7. Further, the mortality in infected aphids with $B$. bassiana increased with increase in spore concentration of conidial suspensions and exposure time. So study clear says that different concentration of $B$. bassiana isolates against $A$. craccivora is dose-time dependent mortality response after application of the pathogenic fungus. By testing their field efficacy, they can be used as a potential entomopathogenic fungus for the sustainable management of $A$. craccivora in fenugreek crop. Furthermore, B. bassiana is considered safer and ecofriendly than chemical insecticides, has wide host range attacking a variety of important pests, can be cultured on relatively inexpensive media and have long shelf life.

\section{ACKNOWLEDGEMENTS}

We are highly thankful to Indian Council of Agricultural Research (ICAR) for providing financial assistance in the form of Junior Research Fellowship (JRF) and to the Head, Department of Entomology for providing facilities for carryout research and $B$. bassiana strain provided by Dr. P.S. Vimaladevi, Directorate of Oilseeds Research (DOR), Hyderabad is duly acknowledged.

\section{REFERENCES}

Abbott, W.S. (1925). A method for computing the effectiveness of an insecticide, Journal of Economic Entomology, 18: 265-267.

AI-Rahmah, A.N., Mostafa, A.A., Abdel-Megeed, A., Yakout, S.M. and Hussein, S.A. (2013). Fungicidal activities of certain methanolic plant extracts against tomato phytopathogenic fungi. African Journal of Microbiology Research, 7(6): 517-524.doi: 10.5897/ AJMR12.1902.

Akmal, M., Freed, S., Malik, M.N. and Gul, H.T. (2013). Efficacy of Beauveria bassiana (Deuteromycotina: Hypomycetes) against different aphid species under laboratory conditions. Pakistan Journal of Zoology, 45 (1): 71-78.

Al-alawi, M.S. and Obeidat, M. (2014). Selection of Beauveria bassiana (Balsamo) Vuillemin isolates for 
management of Myzus persicae (Sultzar) (Homoptera: Aphidae) based on virulence and growth related characteristics. American Journal of Agricultural and Biological Sciences, 9 (1): 94-100. doi:10.3844/ajabssp. 2014.94.100.

Chen, W.W and Feng, M.G. (1999). Evaluation on the potential of four imported isolates of Paecilomyces fumosoroseus as microbial control agents toward the green peach aphid, Myzus persicae. Journal of Zhejiang University-Agriculture and Life Science, 25: 563-568.

Aswini, G.V. (2006). Evaluation of fungal pathogen Fusarium semitectum Berk and Ravenel against sugarcane woolly aphid Ceratovacuna lanigera Zehntner (Homoptera: Aphididae). M.Sc. (Agri.) Thesis, University of Agricultural Sciences, Bangalore, India.

Deshwal, H.L. (2007). Management of insect- pests of fenugreek, Trigonella foenum graecum L. Ph.D Thesis submitted to Rajasthan Agricultural University, Bikaner S.K.N. College of Agriculture, Jobner. P.151

Feng, M.G., Johnson, J.B and Krish, L.P. (1990). Virulence of Verticillium lecanii and an aphid-derived isolate of Beauveria bassiana (Fungi: Hyphomycetes) for six species of cereal aphids (Homoptera: Aphididae). Environmental Entomology, 19: 1534-1542.

Farhana, K., Islam, H., Emran, E.H. and Islam, N. (2006). Toxicity and repellant activity of three spice materials on Tribolium castaneum (Herbst) adults. Journal of Bio -Science, 14:127-130.

Finney, D.J. (1971). Probit analysis. A statistical treatment of the sigmoid response curve. London. Cambridge University Press. 100pp.

Hajek, A.E. and Delalibera, I. (2010). Fungal pathogens as classical biological control agents against arthropods. BioControl, 55: 147-158

Ibrahim, L., Hamieh, A., Ghanem, $\mathrm{H}$ and Ibrahim, S.K. (2011). Pathogenicity of entomopathogenic fungi from lebanese soils against aphids, whitefly and non-target beneficial insects. International Journal of Agriculture Sciences, 3 (3): 156-164.

Kim, K., Vu, V.H., Hong, S. (2008). Selection of entomopathogenic fungi for aphid control. AbstractsJournal of Biotechnology, 136S:S290-S344

Latge, J.P and Papierok, B. (1988). Aphid pathogens. Aphids, their Biology, Natural Enemies and Control (Eds. Minks A K and Harrewijn P). Vol. 2 Elsevier, Amsterdam, The Netherlands, pp 323-335.

Liu, H., Skinner, M., Parker, B.L. and Brownbridge, M. (2002). Pathogenicity of Beauveria bassiana, Metarhizium anisopliae (Deuteromycotina: Hyphomycetes), and other entomopathogenic fungi against Lygus lineolaris (Hemiptera: Mirridae). Journal of Economic Entomology, 95: 675-681.

Meghwal, M. and Goswami, T.K. (2012). A review on the functional properties, nutritional content, medicinal utilization and potential application of fenugreek. Journal of Food Processing and Technology, 3:181. doi:10.4172/2157-7110.100018

Milner, R.J. (1997). Prospects for biopesticides for aphid control. Entomophaga, 42:227-239

Nirmala, R., Ramanujan, B., Rabindra, R.J and Rao, N.S. (2006). Effect of entomofungal pathogens on mortality of three aphid species. Journal of Biological Control, 20 (1): 89-94.

Saranya, S., Ushakumari, R., Jacob, S and Philip, B.M (2010). Efficacy of different entomopathogenic fungi against cowpea aphid, Aphis craccivora (Koch). Journal of Biopesticides, 3(1): 138-142.

Selvaraj, K., Kaushik, H.D., Gulati, R. and Sharma, S.S. (2010). Bioefficacy of Beauveria bassiana (Balsamo) Vuillemin against coriander aphid, Hyadaphis coriandri (Das) on coriander and Aphis craccivora Koch on fenugreek. Journal of Biological Control, 24(2): 142146.

Sharma, S.S and Kalra, V.K.(2002). Assessment of seed yield losses caused by Aphis craccivora (Koch.) in fenugreek. Forage Research, 28(3): 183-184.

Singh, B., Kaur, R. and Singh, K. (2008). Characterization of Rhizobium strain isolated from the roots of Trigonella foenum-graecum (fenugreek). African Journal of Biotechnology, 7 (20): 3671-3676. Doi: 10.5897/ ajb08.752

Suresh, B.C., Khan, H.K. and Prasanna, P.M. (2012). Efficacy of different entomopathogenic fungi against cowpea aphid, Aphis craccivora Koch under laboratory and field condition. International Journal of Plant Protection, 5(1): 68-71.

Thomas, K.J., Selvanayagam, M., Raja, N. and Ignacimuthu, S. (2002). Plant products in controlling rice weevil, Sitophilus oryzae. Journal of Scientific and Industrial Research, 61: 269-274.

Vimaladevi, P.S. (2005). Role of entomopathogenic fungi in insect pest management. Winter school on bio-intensive integrated management of insect pests and diseases of crops. Directorate of Oilseeds Research, Hyderabad, pp 49-54.

Wraight, S.P. and Carruthers, R.I. (2010). Production, delivery and use of mycoinsecticides for control of insect pests of field crops. In: Biopesticides: Use and Delivery, Hall, F.R. and J.J. Menn (Eds.), Humana Press, Totowa, NJ. pp: 233-270.

Wright, M.S., Raina, A.K. and Lax, A.R. (2005). A strain of the fungus Metarhizium anisopliae for controlling subterranean termites. Journal of Economic Entomology, 98: 1451-1458.

Yadav, R.K., Kalia P., Kumar, R. and Jai, V. (2013). Antioxidant and nutritional activity studies of green leafy vegetables. International Journal of Agriculture and Food Science Technology, 4(7): 707-712.

Vu, V.H., Hong, S. and Kim, K. (2007). Selection of entomopathogenic fungi for aphid control. Journal of Bioscience and Bioengineering, 104 (6): 498-505. doi: 10.1263/jbb.104.498 